\title{
BLOOD PRESSURE AND PULSE RATE RESPONSES TO EXTUBATION WITH AND WITHOUT PRIOR TOPICAL TRACHEAL ANAESTHESIA
}

\author{
Arun V. Bidwai, Theodore H. Stanley, and Vanamala A. Bidwal
}

INCREASES IN HEART RATE and blood pressure are common during light planes of anaesthesia at the end of operation and just prior to extubation. Increases in heart rate and blood pressure produce an elevation in cardiac work and oxygen demand and, in patients with coronary artery disease, can lead to myocardial ischaemia. ${ }^{1}$ Extubation during deep planes of anaesthesia avoids cardiac stimulation but produces depression of the respiratory and circulatory systems and occasionally results in difficulty in management of the upper airway. Tracheal anaesthesia with kidocaine sprayed down the tracheal tube at the end of operation has been suggested as a method which permits patients to be extubated during light planes of anaesthesia without producing increases in blood pressure and heart rate. ${ }^{2}$ However, the blood pressure and pulse rate responses to the manoeuvre have not been carefully evaluated. This study was undertaken to investigate and to compare blood pressure and pulse rate responses to extubation during light general anaesthesia with and without lidocaine topical anaesthesia of the trachea.

\section{MeTHODS}

Fifty patients in ASA physical status I or II who were undergoing elective lower abdominal general surgical or gynaecological procedures or lower extremity orthopedic operations were the experimental subjects. Informed written consent was obtained from every patient at the preoperative visit.

All patients were premedicated with hydroxyzine hydrochloride 75 to $100 \mathrm{mg}$, meperidine 50 to $75 \mathrm{mg}$ and atropine 0.3 to $0.5 \mathrm{mg}$ intramuscularly 90 minutes before the scheduled operation.

Arun V. Bidwai, M.D., Instructor in Anaesthesiology, University of Utah and Staff Anaesthesiologist, Holy Cross Hospital. Theodore H. Stanley, M.D., Associate Professor Anaesthesiology/Surgery. Vanamala A. Bidwai, M.D. Adjunet Fellow in Anaesthesiology. Departments of Anaesthesiology, The University of Utah College of Medicine, 50 North Medical Drive, Salt Lake City, Utah, 84132, and the Holy Cross Hospital, 1045 E. 100 South, Salt Lake City, Utah, 84102.
Anaesthesia was induced with sodium methohexitone 1 to $1.5 \mathrm{mg} / \mathrm{kg}$ intravenously, the trachea was intubated after administration of succinylcholine $1.5 \mathrm{mg} / \mathrm{kg}$ and anaesthesia was maintained with halothane 0.5 to 1.5 per cent and 50 per cent nitrous oxide in oxygen. Muscle paralysis was achieved with an intermittent infusion of a 0.1 per cent solution of succinylcholine in lactated Ringer's solution.

Patients were randomly divided into two groups of 25 each with regard to management of extubation at the end of operation. Group A patients had $1.5 \mathrm{ml}$ of lidocaine 4 per cent sprayed down the tracheal tube, using a $3 \mathrm{ml}$ syringe and a 22-gauge needle, 3 to 5 minutes before extubation, when the halothane concentration ( 0.3 to 0.5 per cent) was judged just adequate to prevent coughing on the tube. Nitrous oxide was discontinued just before extubation, the tracheal tube cuff was slowly deflated and $1.0 \mathrm{ml}$ of lidocaine 4 per cent was sprayed through the tube while it was slowly withdrawn. Following extubation pure oxygen was given by face mask. Blood pressure and heart rate were recorded before the initiallidocaine spray, at the time of extubation, just after extubation, and upon entering the recovery room. Group B patients received no lidocaine spray but otherwise were treated similarly and had data recorded at the same time as those in Group A. Data were evaluated for statistical significance using Student's paired t-test for comparison of changes from control in each group or unpaired t-test for comparison of changes from control in group A vs group B.

\section{RESULTS}

Both groups had similar blood pressures and pulse rates five minutes before extubation (Tables I and II). Group A patients did not have a significant elevation in systolic or diastolic blood pressure or pulse rate at or after extubation or in the recovery room. In contrast, group B patients had significant $(P<0.05)$ increases in both pressures and pulse rate at extubation which were more significant immediately after extubation and even greater upon arrival in the recovery 
TABLE 1

Blood Pressure and Pulse Rate Responses to Extubation Group a Patients Who Had lidocaine Injected Down Their Tracheal Tubes (Mean \pm SD)

\begin{tabular}{|c|c|c|c|c|c|}
\hline & \multicolumn{4}{|c|}{ Blood pressure } & \multirow{3}{*}{$\begin{array}{l}\text { Heart rate } \\
\text { (beats } / \mathrm{min} \text { ) }\end{array}$} \\
\hline & \multicolumn{2}{|c|}{ Systolic } & \multicolumn{2}{|c|}{ Diastolic } & \\
\hline & $\mathrm{kPa}$ & Torr & $\mathrm{kPa}$ & Torr & \\
\hline $\begin{array}{l}\text { Five minutes before } \\
\text { extubation } \\
\text { At extubation } \\
\text { One minute after extubation } \\
\text { In recovery room } \\
\text { ( } 5 \text { minutes after extubation) }\end{array}$ & $\begin{array}{l}15.43 \pm 1.33 \\
15.69 \pm 1.33 \\
15.96 \pm 1.33 \\
16.49 \pm 1.2\end{array}$ & $\begin{array}{l}116 \pm 10 \\
118 \pm 10 \\
120 \pm 10 \\
124 \pm 9\end{array}$ & $\begin{array}{r}9.84 \pm 0.93 \\
10.37 \pm 1.06 \\
10.37 \pm 1.06 \\
10.64 \pm 1.2\end{array}$ & $\begin{array}{l}74 \pm 7 \\
78 \pm 8 \\
78 \pm 8 \\
80 \pm 9\end{array}$ & $\begin{array}{l}76 \pm 8 \\
80 \pm 7 \\
86 \pm 11 \\
84 \pm 9\end{array}$ \\
\hline
\end{tabular}

TABLE II

Blood Pressure and Pulse Rate Responses to Extubation in Group B Patients Who Did Not Have Lidocaine Inected Down ThejR Tracheal Tubes (Mean \pm SD)

\begin{tabular}{|c|c|c|c|c|c|}
\hline & \multicolumn{4}{|c|}{ Blood pressure } & \multirow{3}{*}{$\begin{array}{c}\text { Heart rate } \\
\text { (beats/min) }\end{array}$} \\
\hline & \multicolumn{2}{|c|}{ Systolic } & \multicolumn{2}{|c|}{ Diastolic } & \\
\hline & $\mathrm{kPa}$ & Torr & $\mathrm{kPa}$ & Torr & \\
\hline \multirow[t]{2}{*}{$\begin{array}{l}\text { Five minutes before } \\
\text { extubation } \\
\text { At extubation } \\
\text { One minute after extubation } \\
\text { In recovery room } \\
\text { ( } 5 \text { minutes after extubation) }\end{array}$} & $\begin{array}{l}14.63 \pm 1.2 \\
15.96 \pm 1.2^{*} \\
18.09 \pm 1.46 \dagger\end{array}$ & $\begin{array}{l}110 \pm 9 \\
120 \pm 9 * \\
136 \pm 11 \dagger\end{array}$ & $\begin{array}{l}9.58 \pm 1.06 \\
10.91 \pm 0.8^{*} \\
11.7 \pm 1.06 \dagger\end{array}$ & $\begin{array}{l}72 \pm 8 \\
82 \pm 6 * \\
88 \pm 8 \dagger\end{array}$ & $\begin{array}{l}80 \pm 7 \\
91 \pm 8^{*} \\
96 \pm 9 \dagger\end{array}$ \\
\hline & $20.75 \pm 1.6$ & $156 \pm 12 \ddagger$ & $12.77 \pm 0.98 \ddagger$ & $96 \pm 7 \ddagger$ & $104 \pm 9 \ddagger$ \\
\hline
\end{tabular}

room. Changes in systolic and diastolic pressures and pulse rate in group $B$ became significantly greater than group $A$ one minute after extubation and in the recovery room.

\section{Discussion}

Increases in arterial blood pressure and heart rate are common at the end of general anaesthesia with tracheal intubation and can lead to cardiac arthythmias, myocardial ischaemia, and myocardial infarction..$^{3.4}$ Intravenous administration of lidocaine has been used as a cough suppressant and as a supplernent to general anaesthesia to prevent reation to tracheal tubes at the end of anaesthesia. ${ }^{5.6}$ While there is evidence that $\mathrm{ex}$ tubation is smoother following intravenous lidocaine administration during general anaesthesia, ${ }^{5,6}$ there are no data available demonstrating that blood pressure responses at the end of operation and following extubation are any different than those observed when a placebo is used instead of lidocaine. ${ }^{5}$ Cough suppression at the end of operation has also been achieved by injecting or spraying lidocaine down the tracheal tube. ${ }^{6}$ The results of this study demonstrate that this manoeuvre prevents increases in arterial blood pressure and heart rate during and after tracheal extubation and in the recovery room.

Our data do not reveal whether the beneficial effects of lidocaine in this study were due to topical anaesthesia of the upper airway or to high lidocaine blood levels from rapid tracheal absorption of the compound and secondary greater general anaesthesia at, and shortly after, extubation. Either of these mechanisms could explain why group A patients experienced no significant change in arterial blood pressures and heart rate with extubation and group B sustained significant elevations in these variables.

Our data also do not indicate whether there is an optimal time for injection or spraying lidocaine down the tracheal tube. However, since lidocaine blood levels quickly diminish following intravenous ${ }^{7}$ or intratracheal ${ }^{8}$ administration and topical local anaesthesia of the upper airway only 
lasts for 20 to 30 minutes, ${ }^{9}$ it is probably important that the time of lidocaine injection be reasonably close to the time of extubation.

\section{SUMmaRY}

The results of this study demonstrate that 60 mig of lidocaine sprayed down the tracheal tube before extubation and $\mathbf{4 0} \mathbf{m g}$ sprayed down during tracheal tube removal prevents increases in blood pressure and pulse rate during and after exlubation. The data suggest that this mancuvre should be of advantage to patients with coronary artery disease who may not be able to tolerate the increased cardiac dynamics which usually accompany extubation.

\section{RÉSUMÉ}

Les auteurs étudient et comparent les rétentissements de l'extubation sur le pouls et la tension artérielle lors d'anesthésie à l'halothane associé au protoxyde d'azote-oxygène avec ou sans anesthésie topique de la trachée à la lidocaïne.

Les données recueillies montrent que l'administration de $1.5 \mathrm{ml}$ de lidocaïne à 4 pour cent par vaporisation dans le tube endotrachéal cinq minute avant l'extubation, suivie de l'administration de $1.0 \mathrm{ml}$ de la même voie lors de l'extraction du tube prévient l'augmentation du pouls et de la tension artérielle pendant et après l'extubation.
Les auteurs en concluent que l'anesthésie topique de la trachée peut s'avérer avantageuse che $x$ les coronariens dont la réserve cardiaque est diminuée.

\section{REFERENCES}

1. Braunwald, E. Control of myocardial oxygen consumption: physiologic and clinical considerations. Am. J. Cardiol. 27:416 (1972).

2. Thatte, W.P. (personal communication).

3. Tarhan, S., Moffitt, E.A., Taylor, W.F., \& GUILIANI, E.R. Myocardial infarction after general anesthesia. J.A.M.A. 220: 1451 (1972).

4. Sopala, J.A., Ponka, J.L., \& Divernoy, W.F.C. Operative and non-operative risks in the cardiac patient. Am. Ger. J. 23: 529 (1975).

5. Philips, O.C., Nelson, A.T., Lyona, W.B.. GrafF, T.D., Harris, L.C., \& Frazier, T.M. Intravenous lidocaine as an adjuvant to general anesthesia: a clinical evaluation. Anesthesiology $21: 112(1960)$ (abstract).

6. Steinhaus, J.E. \& Gaskin, L.A. A sludy of intravenous lidocaine as a suppressant of cough reflex. Anesthesiology 24: 285 (1963).

7. Covino, B.G. \& Vassallo, H.G. Pharmacokinetic a spects of local anesthetic agents. Local ines. thetics - Mechanism of action and clinical use. New York, Grune \& Stratton, pp. 105, (1976).

8. Vegas, O. \& Stoelting, R.K. Lidocaine in arterial blood after laryngotracheal administration. Anesthesiology 43:491 (1975).

9. Covino, B.G. \& VASSAllo, H.G. Clinical aspects of local anesthesia. Local anesthetics - mechanisms of action and clinical use. New York, Grune \& Stratton, pp. 105 (1976). 